\title{
Advances in Understanding Mechanisms of Thalamic Relays in Cognition and Behavior
}

\author{
(D)Anna S. Mitchell, ${ }^{1}{ }^{-}$S. Murray Sherman, ${ }^{2}$ Marc A. Sommer, ${ }^{3}$ - Robert G. Mair, ${ }^{4}$ Robert P. Vertes, ${ }^{5}$ \\ and Yogita Chudasama ${ }^{6}$ \\ ${ }^{1}$ Department of Experimental Psychology, Oxford University, Oxford OX1 3UD, United Kingdom, ${ }^{2}$ Department of Neurobiology, University of Chicago, \\ Chicago, Illinois 60637, ${ }^{3}$ Department of Biomedical Engineering, Duke University, Durham, North Carolina 27708, ${ }^{4}$ Department of Psychology, University \\ of New Hampshire, Durham, New Hampshire 03824, ${ }^{5}$ Center for Complex Systems and Brain Sciences, Florida Atlantic University, Boca Raton, Florida \\ 33431, and ${ }^{\circ}$ Department of Psychology, McGill University, Montreal, Quebec H3A 1B1, Canada
}

The main impetus for a mini-symposium on corticothalamic interrelationships was the recent number of studies highlighting the role of the thalamus in aspects of cognition beyond sensory processing. The thalamus contributes to a range of basic cognitive behaviors that include learning and memory, inhibitory control, decision-making, and the control of visual orienting responses. Its functions are deeply intertwined with those of the better studied cortex, although the principles governing its coordination with the cortex remain opaque, particularly in higher-level aspects of cognition. How should the thalamus be viewed in the context of the rest of the brain? Although its role extends well beyond relaying of sensory information from the periphery, the main function of many of its subdivisions does appear to be that of a relay station, transmitting neural signals primarily to the cerebral cortex from a number of brain areas. In cognition, its main contribution may thus be to coordinate signals between diverse regions of the telencephalon, including the neocortex, hippocampus, amygdala, and striatum. This central coordination is further subject to considerable extrinsic control, for example, inhibition from the basal ganglia, zona incerta, and pretectal regions, and chemical modulation from ascending neurotransmitter systems. What follows is a brief review on the role of the thalamus in aspects of cognition and behavior, focusing on a summary of the topics covered in a mini-symposium held at the Society for Neuroscience meeting, 2014.

\section{Introduction}

The best-studied aspects of thalamic function relate to its role as a sensory relay. However, the complexity of its anatomical connections, the effects of thalamic lesions, and electrophysiological activity in behaving animals have made it clear that its role in cognition is much more comprehensive. The thalamus can be subdivided into many different nuclei based on anatomical, functional, and chemical differences. Many of these nuclei are routinely identified as elements in large-scale networks dedicated to specific aspects of cognitive behavior. The essential cognitive contributions of the thalamus can be gleaned from patient studies. For example, the thalamus is a key structure in the domain of memory, and its injury can result in diencephalic amnesia. Specifically, disconnection of the anterior portions of the thalamus from the hippocampus and retrosplenial cortex is associated with

Received Aug. 8, 2014; revised Sept. 26, 2014; accepted 0ct. 3, 2014.

This work was supported by Medical Research Council Fellowship G0800329 to A.S.M., National Eye Institute Grant EY-022338 and National Institute of Deafness and 0ther Communication Disorders Grant DC-008794 to S.M.S., National Institute of Mental Health Grant MH099590 to R.P.V., National Eye Institute Grants R01EY017592 and R21EY022788 and an Alfred P. Sloan Research Fellowship to M.A.S., New Ventures Fund from the University of New Hampshire to R.G.M., and Natural Sciences and Engineering Research Council of Canada Grant 341600 and Canadian Institutes of Health Research Grant 102507 to Y.C. We thank Dr. David A. Leopold and Dr. Ray W. Guillery for helpful comments on the manuscript.

The authors declare no competing financial interests.

Correspondence should be addressed to Dr. Yogita Chudasama, Department of Psychology, McGill University, Montreal, Quebec H3A 1B1, Canada. E-mail: yogita.chudasama@mcgill.ca.

DOI:10.1523/JNEUROSCI.3289-14.2014

Copyright $\odot 2014$ the authors $\quad 0270-6474 / 14 / 3415340-07 \$ 15.00 / 0$ memory loss (Valenstein et al., 1987; Graff-Radford et al., 1990; Maguire, 2001; Aggleton et al., 2010; Aggleton, 2012). The thalamus is also implicated in several aspects of executive function. For example, damage to midline thalamic nuclei cause a range of deficits related to attention, impulse control, and decision-making (Daum and Ackermann, 1994; Van der Werf et al., 2003; Carrera and Bogousslavsky, 2006). The thalamus is also related to the internal monitoring of actions, spatial perception, planning and response selection, with damage to posterior (Karnath et al., 2002) or central (Ostendorf et al., 2010) thalamus resulting in deficits of visuomotor coordination (Rafal and Posner, 1987; Gaymard et al., 1994).

Further to the insights gained from studies of patients, targeted work in animals has added precision to our understanding of thalamic contributions to cognition. In this article, we review recent experimental findings that shed light on the role of the thalamus in aspects of cognition and behavior. We begin by briefly outlining the general principles governing the functional connections of the thalamus. This is followed by a description of recent anatomical studies using both conventional and viral tracing methods to address specific thalamic circuits related to aspects of cognition. The wiring of the thalamocortical pathways is then tied to function, as we examine neural activity in thalamic nuclei during complex behavior. Finally, we examine the critical influence of thalamic circuits on cognitive behavior in animals with selective lesions of well-defined thalamic subregions. We begin with a brief review of the principles governing the functional connections between the thalamus and cortex. 


\section{The thalamus as a relay to the cortex}

The main output of projection neurons in most thalamic nuclei is the neocortex, with exceptions, such as the striatum, amygdalae, and hippocampus. The input to these same thalamic neurons draws from a considerably wider range of sources, including the neocortex, basal ganglia, cerebellum, and various subcortical sources. Thus, with respect to the thalamocortical interplay, it is legitimate to ask what neural connections are primarily responsible for driving the activity of thalamic relay neurons.

Work that has focused on visual thalamic nuclei suggests that identifying the "driving" inputs to thalamic neurons, that is, the inputs that are actually relayed to cortex may be key to understanding the larger thalamic circuitry. Even primary sensory relays, such as the lateral geniculate nucleus (LGN), whose driving input is clearly the retina, receives a wide range of input, including GABAergic input from interneurons and the thalamic reticular nucleus, glutamatergic input from cortical layer 6, as well as cholinergic and other neurotransmitter inputs from the brainstem (Sherman and Guillery, 1996, 2002). Although retinal inputs contribute the minority of synapses to the LGN relay cells, they are unambiguously the drivers of LGN activity. The key to understanding this apparent paradox is that their synaptic connections are stronger and operate on a rapid time scale necessary for transmission of the relevant messages. Throughout the thalamus, there is a dichotomy of synaptic profiles: certain strong, proximal synapses can reliably propagate signals from across the synapse, whereas weaker distal synapses are relegated to a modulatory role (Theyel et al., 2010; Lee and Sherman, 2011; Viaene et al., 2011). Driver synapses, which in thalamus include only glutamatergic synapses, activate only ionotropic receptors postsynaptically. Glutamatergic modulator synapses activate both ionotropic and metabotropic receptors postsynaptically (as is the case for "classical" modulator inputs, e.g., cholinergic, noradrenergic) and serve mainly to influence how the driver message is relayed through thalamus rather than providing a message for relay. Inhibitory inputs may be another form of modulation because these affect the relay of driver inputs (e.g., through gating) rather than providing a message for relay.

The driver/modulator dichotomy is further useful in understanding the detailed wiring of sensory-recipient ("first-order") versus cortico-recipient ("higher-order") thalamic relays. Higher-order relays, like first-order relays, receive both driver and modulator inputs from glutamatergic neurons. For firstorder relays, the driver input comes from subcortical sources, such as retinal input to the LGN, but many of the driver inputs to higher-order relays, such as the pulvinar and mediodorsal thalamus (MD), come from large layer 5 pyramidal neurons (Schwartz et al., 1991). Thus, all thalamic relays receive a modulator input from layer 6 pyramidal cells that is organized in a feedback manner, and the higher-order relays in addition receive a feedforward layer 5 input (Sherman and Guillery, 2002; Sherman, 2007). A particularly intriguing aspect of this organization is the notion that the main driving inputs to the thalamus, arising from layer 5, are closely associated with action commands of the cerebral cortex to downstream motor centers through axon collaterals of the inputs to thalamus (Guillery and Sherman, 2002). This suggests that a key role of the thalamus may be to relay information about ongoing instructions to the cortex (Wurtz et al., 2011). Most relevant for this article, this evidence suggests that higher-order thalamic relays can be viewed as an essential link in corticothalamocortical processing (Sherman, 2012).

To what extent do other subregions of the thalamus, which have not been directly studied in this way, act as higher-order relays with drivers and modulators as inputs? Although it is premature to give a complete answer to this question, there is increasing evidence that diverse nonsensory nuclei in the MD thalamus, midline thalamus, and intralaminar thalamus share the role of relaying information from one cortical region to another (Vertes and Hoover, 2008; Aggleton, 2012; Prasad and Chudasama, 2013). The midline and intralaminar thalamic nuclei, initially clumped together and described as "nonspecific" because of their widespread distribution of efferent fibers over the entire cerebral cortex (Morison and Dempsey, 1941; Dempsey and Morison, 1942; Royce et al., 1989), serve as an excellent example. Each of these nuclei is, indeed, quite specific in both the afferents they receive and the targets to which they project. Several individual midline nuclei project to distinct subregions of the cortex and hippocampus (Herkenham, 1978; Su and Bentivoglio, 1990; Wouterlood et al., 1990; Berendse and Groenewegen, 1991; Vertes et al., 2006). Other midline and intralaminar nuclei target subregions of the striatum (Berendse and Groenewegen, 1990; Su and Bentivoglio, 1990; Vertes et al., 2012) and amygdala (Berendse and Groenewegen, 1990; Moga et al., 1995; Li and Kirouac, 2008). Through these connections, the dorsal midline and intralaminar complex can serve as relay stations between specific parts of the prefrontal and cingulate cortex and the striatum (Berendse and Groenewegen, 1990; Groenewegen and Berendse, 1994; Van der Werf et al., 2002; Vertes et al., 2012). The ventral midline nuclei, namely, the nucleus reuniens $(\mathrm{Re})$ and rhomboid nucleus, are likewise thought to relay information between the prefrontal cortex and medial temporal lobe (for review, see Cassel et al., 2013). The Re, for example, has strong reciprocal connections with the ventral prelimbic, infralimbic, and orbitofrontal cortex, as well as the CA1/subiculum of the ventral hippocampus (Su and Bentivoglio, 1990; Wouterlood et al., 1990; Vertes, 2002; McKenna and Vertes, 2004; Vertes, 2004). Moreover, 10\% of neurons in the Re have collaterals to both the ventral prefrontal cortex and the ventral hippocampus, suggesting that, in its role as a relay, the Re has a powerful influence on two very different cortical projection sites (Hoover and Vertes, 2012).

More recently, certain transsynaptic viral tracers, such as the pseudorabies virus-Bartha strain, demonstrated thalamic pathways embedded in functional circuits in more detail than conventional tracers. This is because the amplification of the virus and retrograde transport across multiple synapses allows for an evaluation of indirect as well as direct anatomical projections (Card et al., 1993; Chen et al., 1999). In accordance with previous notions about the thalamus serving as a relay between the prefrontal cortex and hippocampus (Vertes et al., 2007), a recent study using this disynaptic tracing approach found evidence for such a relay within the midline thalamus (Prasad and $\mathrm{Chu}$ dasama, 2013). That study identified two parallel pathways from the limbic cortex to the hippocampus, with thalamic labeling that was consistent with a role as a primary relay. In the dorsal pathway, input to the dorsal hippocampus originates in retrosplenial, anterior cingulate, and orbitofrontal cortex and passes through a putative synaptic relay in the anterior thalamic nuclei. Likewise, in the ventral pathway, the ventral hippocampus receives input from the ventral and orbital prefrontal cortex, potentially relayed via the midline thalamic nuclei (Prasad and Chudasama, 2013). These recent findings support the notion that the thalamus, part of the diencephalon, acts as a relay between the cortex and hippocampus, two prominent regions of the telencephalon. 


\section{Diverse neural signals in the prefrontal-projecting thalamus} Although anatomical tracing studies are key to mapping the organization of thalamic relay pathways, it is also of great value to understand the meaning of the electrophysiological signals carried by thalamic relay neurons in its communication with the cerebral cortex. Electrophysiological studies using rats (Mair et al., 2014) and monkeys (Sommer and Wurtz, 2006) have investigated the types of signals relayed from the MD thalamus to its targets in the frontal cortex. From these studies alone, it is evident that this thalamic subdivision carries diverse signals to frontal areas, including high-level correlates related to a cognitive task as well as basic corollary discharge copies of brainstem sensorimotor signals. In both cases, the MD functioning as a relay to cortex has important implications for cognitive function. We start with the MD thalamus as a sensorimotor relay.

The thalamus is the recipient of a wide range of inputs from brain structures associated with movement, with certain nuclei receiving input from the cerebellum (Sakai et al., 2002; Kelly and Strick, 2003), the basal ganglia (Middleton and Strick, 2000), or cortical regions involved in motor execution (Stanton et al., 1988). Recent work has demonstrated that it is also the recipient of brainstem signals related to the execution of saccades, which it passes along to oculomotor control regions of the frontal cortex (Sommer and Wurtz, 2008). Previous anatomical studies have shown that the eye movement-related layers of the superior colliculus project to lateral MD neurons (Benevento and Fallon, 1975; Harting et al., 1980), which in turn project almost exclusively to the frontal eye fields (Barbas and Mesulam, 1981; Goldman-Rakic and Porrino, 1985; Lynch et al., 1994). Sommer and Wurtz (2002) identified the most lateral edge of MD as a critical relay that transmitted signals from the superior colliculus to frontal eye fields in behaving monkeys. They used a combination of antidromic stimulation (backfiring neurons with electrical stimulation from frontal eye fields) and orthodromic stimulation (synaptically driving the neuron from superior collinculus) to specify those MD projection neurons that served this relay function. What role might this type of oculomotor relay play in cognitive behavior? The answer lies in the concept of corollary discharge, which is a signal generated simultaneously with a movement and is passed along to allow other brain areas to take that movement into account in planning future movements (Wurtz and Sommer, 2004). In the case of saccadic eye movements, the relay of corollary discharge signals from superior colliculus through the thalamus to frontal eye fields allows for the planning of an impending action or sequences of responses, based on knowledge that a particular eye movement has, indeed, occurred (Wurtz et al., 2011). In a series of electrophysiological studies, Sommer and Wurtz (2002, 2004a, b) studied the activity of lateral MD neurons while monkeys performed delayed saccades to visual targets. Importantly, they showed that MD inactivation impaired information about executed saccades to the frontal cortex, disrupting sequential eye movement behavior and predictive visual updating in frontal eye field neurons (Sommer and Wurtz, 2006). Corollary discharge signals from superior colliculus are integrated in frontal cortex, providing each frontal eye field with information about the full range of saccades (Crapse and Sommer, 2009), and the integration starts as early as thalamic-recipient layer 4 (Shin and Sommer, 2012). The internal monitoring of actions provided by this MD-mediated pathway therefore seems critical to cognitive-executive control, in that it appears to guide decisions about how to sample a complex scene. The results are also broadly consistent with Sherman and Guillery's concept that the thalamus is a recipient of motor plans
(Sherman and Guillery, 2002), in this case with the motor signal arising either in the cerebral cortex or from ascending pathways.

Mair et al. (2014) have also studied the electrophysiological responses in area MD in the rat, albeit from a somewhat different perspective. In their experiments, they asked how MD neurons projecting to prefrontal cortex would respond during complex cognitive tasks. Previous experiments disrupting MD in rats have suggested that it is a critical node for influencing prefrontal working memory (Stokes and Best, 1990; Harrison and Mair, 1996; Floresco et al., 1999; Romanides et al., 1999; Mitchell and Dalrymple-Alford, 2005). In rats, there is substantial reciprocity in the projections between the MD and prefrontal cortex; the medial portion of the MD not only sends its major output to the ventral and orbital prefrontal cortex, it receives direct input from these very same regions (Krettek and Price, 1977; Groenewegen, 1988). What kind of activity would MD relay neurons show relative to the signals observed on their cortical inputs and outputs? If the MD thalamus is strongly driven by prefrontal cortex cells, or if it strongly drives prefrontal cortex neurons, then one might expect that neurons in the two regions would show similar response profiles. Mair et al. (2014) addressed this issue directly by recording event-related activity of single neurons in both the prefrontal cortex and in MD of rats performing a working memory task. They found that neuronal activity in the prefrontal cortex was directly linked to a wide variety of events related to working memory, including planning and execution of response (Onos et al., 2013), also shown by several others (e.g., Jung et al., 2000; Baeg et al., 2003; Horst and Laubach, 2012). Although many MD neurons exhibited responses comparable with prefrontal neurons, MD neurons tended to exhibit higher levels of tonic activity and thus lower signal-to-noise ratios than prefrontal neurons when rats performed the working memory task. Delay period activity was also observed but tended to be brief, consistent with the recent report that, unlike prefrontal neurons, MD neurons fail to adequately signal an upcoming choice (Han et al., 2013). Other MD neurons exhibited suppressed activity related to actions, action-outcomes, and memory delays that were not observed in the prefrontal cortex (Miller et al., 2013). Mair et al. (2014) also examined the effects of unilateral thalamic inhibition on prefrontal activity. Muscimol was microinjected in medial thalamic sites at doses previously shown to impair working memory (Mair and Hembrook, 2008). Unilateral inactivation substantially reduced prefrontal activity on the ipsilateral side but with minimal effect on behavioral performance. Other recent data, coupling pharmacogenetics and electrophysiology in behaving mice, have shown that a decrease in the firing of MD neurons significantly disrupts MD-prefrontal synchrony, and this is correlated with deficits in working memory (Parnaudeau et al., 2013). Together, these results confirm the important influence of MD on the prefrontal cortex. The close correspondence between event-related responses for many neurons in $\mathrm{MD}$ and prefrontal cortex is consistent with the strong corticothalamic and thalamocortical connections between these areas. The nature of the interactions between prefrontal signals and other inputs to MD remains an open question, one that is somehow representative of the ongoing mystery regarding the significance of electrophysiological signals measured among higher order thalamic relay neurons.

\section{Cognitive effects of disrupting thalamic relays}

In the final section, we examine how disruption of the thalamic circuitry can lead to cognitive deficits. It is well known that certain types of thalamic damage in human patients can lead to 
deficits in memory, attention, and spatial perception. In animal studies, it is possible to direct lesions to very precise thalamic subregions of which the anatomical connectivity has been explicitly studied. Two of the speakers in the symposium have examined the effect of excitotoxic lesions to regions of the thalamus that project to the prefrontal cortex, in one case in monkeys and in the other in rats.

In monkeys, $\mathrm{MD}$ is a large nucleus that is interconnected to several prefrontal subdivisions. The connections between its medial, magnocellular division (MDmc) and the ventromedial and orbital prefrontal cortex are reciprocal. There are also nonreciprocal inputs to the MDmc from medial and ventrolateral regions of the prefrontal cortex (Goldman-Rakic and Porrino, 1985; Barbas et al., 1991; Bachevalier et al., 1997; McFarland and Haber, 2002).

Recent work has examined the effect of selective damage to $\mathrm{MDmc}$ in monkeys on their capacity to learn and remember object-in-place discriminations (Mitchell and Chakraborty, 2013; for review, see Baxter, 2013). In these studies, monkeys were presented with complex visual scenes embedded with two objects, of which only one object was correct (i.e., rewarded). Monkeys learned hundreds of discriminations and showed good memory of them in a probe retention test. In some cases, monkeys were required to implement a particular visuomotor strategy to obtain reward. After the MDmc lesion, these monkeys were unable to learn and remember new sets of visual scenes, reflecting a state of anterograde amnesia (Mitchell et al., 2007; Mitchell and Gaffan, 2008). However, the same animals showed no sign of retrograde amnesia and had good retention of the preoperatively learned visual scenes. Of particular interest to this article, however, is the finding that the MDmc lesion did not affect problem solving skills in situations that involved complex visuomotor strategies learnt before brain injury (Mitchell et al., 2007; Mitchell and Gaffan, 2008). This finding might be seen as unexpected because lesions to a cortical input of $\mathrm{MDmc}$, the ventrolateral prefrontal cortex, resulted in severe impairment on this visuomotor strategy task (Baxter et al., 2008, 2009). Similarly, surgical studies effectively disconnecting frontal and temporal lobe regions severely impaired preoperatively acquired visuomotor strategies (Gaffan et al., 2002). The lack of such effects for MDmc lesions indicates that its functional role in this task differs from that of cortical regions with which it is most strongly interconnected. It has been proposed that MDmc ablation disrupts its thalamic relay function and thereby disrupts corticocortical communication during new learning of information and strategies rather than during retention (Mitchell and Gaffan, 2008; Mitchell et al., 2008). This role as a relay may be particularly important for understanding communication between frontal and medial temporal lobes (Kopelman et al., 1997; Harding et al., 2000; Mitchell et al., 2008) and is supported by the known anatomical connections in primates (Aggleton, 1986; Russchen et al., 1987; Goulet et al., 1998; Saunders et al., 2005).

Finally, evidence suggests that MD may also contribute more generally to adaptive decision-making. Following MD lesions, monkeys and rats are unable to form expectations about the desirability or value of an impending event (Corbit et al., 2003; Mitchell et al., 2007; Ostlund and Balleine, 2008; Izquierdo and Murray, 2010; Parnaudeau et al., 2014) and are therefore unable to use this information to establish the appropriate course of action (for review, see Bradfield et al., 2013). Here, the contribution of MD may be to facilitate the interaction between the orbital prefrontal cortex and basolateral amygdala (Ostlund and Bal- leine, 2008; Izquierdo and Murray, 2010), again underscoring its potentially important role as a frontotemporal relay.

Studying a somewhat different frontotemporal circuit in the rat, Chudasama and Prasad (2012) have examined the effects of targeted brain injury to midline thalamic relays, and especially the nucleus reuniens $(\mathrm{Re})$ on specific prefrontal functions, such as attention, impulse control, and decision-making. They took advantage of the five choice reaction time task to dissect these aspects of executive function in normal and lesioned animals. In this task, rats are required to quickly and accurately detect the random occurrence of brief light stimuli while controlling impulsive urges to respond or retrieve food at the wrong times (for review, see Chudasama and Robbins, 2004, 2006). Under easy task conditions, with long stimulus presentations, rats with focal Re lesions showed normal attention. However, when the task was made more difficult by presenting only a very brief light whose location needed to be retained in working memory, the Re lesion had the seemingly paradoxical effect of improving task performance. Closer inspection of behavioral data in the lesioned animals revealed that, compared with the control animals, they were intensely focused on the stimuli and less distracted during the trial. This focus resulted in high response accuracy, fast responses, and a much lower than usual fraction of impulsive responses (Chudasama and Prasad, 2012). Small lesions within the Re thus prompted the animals to behave as if they were highly aroused and focused on the task at hand. This behavior is entirely different than the effects of damage to either the ventral prefrontal cortex or ventral hippocampus, both of which exchange projections with this thalamic nucleus. Moreover, these data are consistent with the results presented above that the thalamic relay nuclei can have somewhat different roles in behavior than the cortical areas to which they project or from which they receive input. One possible interpretation of these results is that thalamic relays are the recipient of abundant neuromodulation and are thus subject to direct control of arousal and wakefulness in a manner that differs from the cortex (Steriade et al., 1990, 1997; Bayer et al., 2002; Jones, 2003; Mair et al., 2011). These modulatory changes, by affecting the excitability and efficacy of a cognitive corticothalamic or thalamocortical circuit, can have a major impact on executive function.

The role of the midline thalamic nuclei in cognition has in recent years received increased attention. Other midline thalamic lesions that include the Re have been shown to impair certain aspects of memory function, especially as it relates to the flexible control of navigation strategies (Dolleman-van der Weel et al., 2009; Cholvin et al., 2013) but fail to disrupt working memory (Chudasama and Prasad, 2012). Recently, Xu and Südhof (2013), using optogenetic methods, showed that the Re outputs to the prefrontal cortex, and prefrontal inputs to the Re enable rats to respond quickly and appropriately to fearful situations. How the $\mathrm{Re}$ is able to contribute to such a wide range of cognitive behaviors is still an active area of research. This relates to reports that individual neurons within this thalamic nucleus send collaterals to both the prefrontal cortex and hippocampus (Hoover and Vertes, 2012), and it is possible that this anatomical organization plays a particular role in frontotemporal coordination.

In conclusion, in this short article, we have highlighted the role of the thalamus in aspects of cognition beyond sensory processing. We have reviewed evidence that implicates the thalamus as contributing directly to cognitive functions as diverse as memory, motivation, decision-making, and the monitoring of selfgenerated actions. At the same time, the specific mechanisms by which the thalamus shapes these cognitions and behaviors re- 
main enigmatic. Although the anatomy of the thalamus is highly complex, its general portrait as a relay derives from its basic anatomy. Nearly all thalamic nuclei, including those featured in the present review, project principally into the telencephalon, targeting the cerebral cortex, hippocampus, or striatum. The most straightforward interpretation is that higher-order regions of the thalamus act as information relays much in the same way as first-order thalamic nuclei act as sensory relays. However, unlike first-order thalamic nuclei, which act as sensory relays carrying signals from the periphery, higher-order relays often receive their afferent projections from cortical areas involved in cognition and behavior. This cortical input shapes the signals carried by neurons in the higher-order thalamic nuclei, from where neurons project to other cortical areas. In this way, the thalamus can facilitate communication between multiple telencephalic regions involved in complex cognition by acting as an information relay. To gain a deeper understanding of the thalamic contribution to cognition, the adequacy of a relay metaphor, and the corticothalamic relationship more generally, future studies must be guided by our ever-increasing knowledge of the complex functional neuroanatomy of the thalamus, its inputs, and its projections.

\section{References}

Aggleton JP (1986) Memory impairments caused by experimental thalamic lesions in monkeys. Rev Neurol (Paris) 142:418-424. Medline

Aggleton JP (2012) Multiple anatomical systems embedded within the primate medial temporal lobe: implications for hippocampal function. Neurosci Biobehav Rev 36:1579-1596. CrossRef Medline

Aggleton JP, O'Mara SM, Vann SD, Wright NF, Tsanov M, Erichsen JT (2010) Hippocampal-anterior thalamic pathways for memory: uncovering a network of direct and indirect actions. Eur J Neurosci 31:2292-2307. CrossRef Medline

Bachevalier J, Meunier M, Lu MX, Ungerleider LG (1997) Thalamic and temporal cortex input to medial prefrontal cortex in rhesus monkeys. Exp Brain Res 115:430-444. CrossRef Medline

Baeg EH, Kim YB, Huh K, Mook-Jung I, Kim HT, Jung MW (2003) Dynamics of population code for working memory in the prefrontal cortex. Neuron 40:177-188. CrossRef Medline

Barbas H, Mesulam MM (1981) Organization of afferent input to subdivisions of area 8 in the rhesus monkey. J Comp Neurol 200:407-431. CrossRef Medline

Barbas H, Henion TH, Dermon CR (1991) Diverse thalamic projections to the prefrontal cortex in the rhesus monkey. J Comp Neurol 313:65-94. CrossRef Medline

Baxter MG (2013) Mediodorsal thalamus and cognition in non-human primates. Front Syst Neurosci 7:38. CrossRef Medline

Baxter MG, Browning PG, Mitchell AS (2008) Perseverative interference with object-in-place scene learning in rhesus monkeys with bilateral ablation of ventrolateral prefrontal cortex. Learn Mem 15:126-132. CrossRef Medline

Baxter MG, Gaffan D, Kyriazis DA, Mitchell AS (2009) Ventrolateral prefrontal cortex is required for performance of a strategy implementation task but not reinforcer devaluation effects in rhesus monkeys. Eur J Neurosci 29:2049-2059. CrossRef Medline

Bayer L, Eggermann E, Saint-Mleux B, Machard D, Jones BE, Mühlethaler M, Serafin M (2002) Selective action of orexin (hypocretin) on nonspecific thalamocortical projection neurons. J Neurosci 22:7835-7839. Medline

Benevento LA, Fallon JH (1975) The ascending projections of the superior colliculus in the rhesus monkey (Macaca mulatta). J Comp Neurol 160: 339-361. CrossRef Medline

Berendse HW, Groenewegen HJ (1990) Organization of the thalamostriatal projections in the rat, with special emphasis on the ventral striatum. J Comp Neurol 299:187-228. CrossRef Medline

Berendse HW, Groenewegen HJ (1991) Restricted cortical termination fields of the midline and intralaminar thalamic nuclei in the rat. Neuroscience 42:73-102. CrossRef Medline

Bradfield LA, Hart G, Balleine BW (2013) The role of the anterior, mediodorsal, and parafascicular thalamus in instrumental conditioning. Front Syst Neurosci 7:51. CrossRef Medline
Card JP, Rinaman L, Lynn RB, Lee BH, Meade RP, Miselis RR, Enquist LW (1993) Pseudorabies virus infection of the rat central nervous system: ultrastructural characterization of viral replication, transport, and pathogenesis. J Neurosci 13:2515-2539. Medline

Carrera E, Bogousslavsky J (2006) The thalamus and behavior: effects of anatomically distinct strokes. Neurology 66:1817-1823. CrossRef Medline

Cassel JC, Pereira de Vasconcelos A, Loureiro M, Cholvin T, Dalrymple-Alford JC, Vertes RP (2013) The reuniens and rhomboid nuclei: neuroanatomy, electrophysiological characteristics and behavioral implications. Prog Neurobiol 111: 34-52. CrossRef Medline

Chen S, Ming X, Miselis RR, Aston-Jones G (1999) Characterization of transsynaptic tracing with central application of pseudorabies virus. Brain Res 838:171-183. CrossRef Medline

Cholvin T, Loureiro M, Cassel R, Cosquer B, Geiger K, De Sa Nogueira D, Raingard H, Robelin L, Kelche C, Pereira de Vasconcelos A, Cassel JC (2013) The ventral midline thalamus contributes to strategy shifting in a memory task requiring both prefrontal cortical and hippocampal functions. J Neurosci 33:8772-8783. CrossRef Medline

Chudasama Y, Prasad JA (2012) Lesions of the thalamic reuniens fail to disrupt working memory but enhance attentional performance. Soc Neurosci Abstr 599-07.

Chudasama Y, Robbins TW (2004) Psychopharmacological approaches to modulating attention in the five-choice serial reaction time task: implications for schizophrenia. Psychopharmacology (Berl) 174:86-98. CrossRef Medline

Chudasama Y, Robbins TW (2006) Functions of frontostriatal systems in cognition: comparative neuropsychopharmacological studies in rats, monkeys and humans. Biol Psychol 73:19-38. CrossRef Medline

Corbit LH, Muir JL, Balleine BW (2003) Lesions of mediodorsal thalamus and anterior thalamic nuclei produce dissociable effects on instrumental conditioning in rats. Eur J Neurosci 18:1286-1294. CrossRef Medline

Crapse TB, Sommer MA (2009) Frontal eye field neurons with spatial representations predicted by their subcortical input. J Neurosci 29:53085318. CrossRef Medline

Daum I, Ackermann H (1994) Frontal-type memory impairment associated with thalamic damage. Int J Neurosci 77:187-198. CrossRef Medline

Dempsey EW, Morison RS (1942) The production of rhythmically recurrent cortical potentials after localized thalamic stimulation. Am J Physiol 135:293-300.

Dolleman-van der Weel MJ, Morris RG, Witter MP (2009) Neurotoxic lesions of the thalamic reuniens or mediodorsal nucleus in rats affect nonmnemonic aspects of watermaze learning. Brain Struct Funct 213:329-342. CrossRef Medline

Floresco SB, Braaksma DN, Phillips AG (1999) Thalamic-cortical-striatal circuitry subserves working memory during delayed responding on a radial arm maze. J Neurosci 19:11061-11071. Medline

Gaffan D, Easton A, Parker A (2002) Interaction of inferior temporal cortex with frontal cortex and basal forebrain: double dissociation in strategy implementation and associative learning. J Neurosci 22:7288-7296. Medline

Gaymard B, Rivaud S, Pierrot-Deseilligny C (1994) Impairment of extraretinal eye position signals after central thalamic lesions in humans. Exp Brain Res 102:1-9. Medline

Goldman-Rakic PS, Porrino LJ (1985) The primate mediodorsal (MD) nucleus and its projection to the frontal lobe. J Comp Neurol 242:535-560. CrossRef Medline

Goulet S, Doré FY, Murray EA (1998) Aspiration lesions of the amygdala disrupt the rhinal corticothalamic projection system in rhesus monkeys. Exp Brain Res 119:131-140. CrossRef Medline

Graff-Radford NR, Tranel D, Van Hoesen GW, Brandt JP (1990) Diencephalic amnesia. Brain 113:1-25. CrossRef Medline

Groenewegen HJ (1988) Organization of the afferent connections of the mediodorsal thalamic nucleus in the rat, related to the mediodorsalprefrontal topography. Neuroscience 24:379-431. CrossRef Medline

Groenewegen HJ, Berendse HW (1994) The specificity of the "nonspecific" midline and intralaminar thalamic nuclei. Trends Neurosci 17:52-57. CrossRef Medline

Guillery RW, Sherman SM (2002) The thalamus as a monitor of motor outputs. Philos Trans R Soc Lond B Biol Sci 357:1809-1821. CrossRef Medline

Han J, Lee JH, Kim MJ, Jung MW (2013) Neural activity in mediodorsal nucleus of thalamus in rats performing a working memory task. Front Neural Circuits 7:128. CrossRef Medline 
Harding A, Halliday G, Caine D, Kril J (2000) Degeneration of anterior thalamic nuclei differentiates alcoholics with amnesia. Brain 123:141154. CrossRef Medline

Harrison LM, Mair RG (1996) A comparison of the effects of frontal cortical and thalamic lesions on measures of spatial learning and memory in the rat. Behav Brain Res 75:195-206. CrossRef Medline

Harting JK, Huerta MF, Frankfurter AJ, Strominger NL, Royce GJ (1980) Ascending pathways from the monkey superior colliculus: an autoradiographic analysis. J Comp Neurol 192:853-882. CrossRef Medline

Herkenham M (1978) The connections of the nucleus reuniens thalami: evidence for a direct thalamo-hippocampal pathway in the rat. J Comp Neurol 177:589-610. CrossRef Medline

Hoover WB, Vertes RP (2012) Collateral projections from nucleus reuniens of thalamus to hippocampus and medial prefrontal cortex in the rat: a single and double retrograde fluorescent labeling study. Brain Struct Funct 217:191-209. CrossRef Medline

Horst NK, Laubach M (2012) Working with memory: evidence for a role for the medial prefrontal cortex in performance monitoring during spatial delayed alternation. J Neurophysiol 108:3276-3288. CrossRef Medline

Izquierdo A, Murray EA (2010) Functional interaction of medial mediodorsal thalamic nucleus but not nucleus accumbens with amygdala and orbital prefrontal cortex is essential for adaptive response selection after reinforcer devaluation. J Neurosci 30:661-669. CrossRef Medline

Jones BE (2003) Arousal systems. Front Biosci 8:s438-s451. CrossRef Medline

Jung MW, Qin Y, Lee D, Mook-Jung I (2000) Relationship among discharges of neighboring neurons in the rat prefrontal cortex during spatial working memory tasks. J Neurosci 20:6166-6172. Medline

Karnath HO, Himmelbach M, Rorden C (2002) The subcortical anatomy of human spatial neglect: putamen, caudate nucleus and pulvinar. Brain 125:350-360. CrossRef Medline

Kelly RM, Strick PL (2003) Cerebellar loops with motor cortex and prefrontal cortex of a nonhuman primate. J Neurosci 23:8432-8444. Medline

Kopelman MD, Stanhope N, Kingsley D (1997) Temporal and spatial context memory in patients with focal frontal, temporal lobe, and diencephalic lesions. Neuropsychologia 35:1533-1545. CrossRef Medline

Krettek JE, Price JL (1977) The cortical projections of the mediodorsal nucleus and adjacent thalamic nuclei in the rat. J Comp Neurol 171:157-191. CrossRef Medline

Lee CC, Sherman SM (2011) On the classification of pathways in the auditory midbrain, thalamus, and cortex. Hear Res 276:79-87. CrossRef Medline

Li S, Kirouac GJ (2008) Projections from the paraventricular nucleus of the thalamus to the forebrain, with special emphasis on the extended amygdala. J Comp Neurol 506:263-287. CrossRef Medline

Lynch JC, Hoover JE, Strick PL (1994) Input to the primate frontal eye field from the substantia nigra, superior colliculus, and dentate nucleus demonstrated by transneuronal transport. Exp Brain Res 100:181-186. Medline

Maguire EA (2001) Neuroimaging, memory and the human hippocampus. Rev Neurol (Paris) 157:791-794. Medline

Mair RG, Hembrook JR (2008) Memory enhancement with event-related stimulation of the rostral intralaminar thalamic nuclei. J Neurosci 28: 14293-14300. CrossRef Medline

Mair RG, Onos KD, Hembrook JR (2011) Cognitive activation by central thalamic stimulation: the Yerkes-Dodson law revisited. Dose Response 9:313-331. CrossRef Medline

Mair RG, Miller RLA, Wormwood BA, Francoeur MJ, Onos KD, Gibson BM (2014) The neurobiology of thalamic amnesia: contributions of medial thalamus and prefrontal cortex to delayed conditional discrimination. Neurosci Biobehav Rev. In press.

McFarland NR, Haber SN (2002) Thalamic relay nuclei of the basal ganglia form both reciprocal and nonreciprocal cortical connections, linking multiple frontal cortical areas. J Neurosci 22:8117-8132. Medline

McKenna JT, Vertes RP (2004) Afferent projections to nucleus reuniens of the thalamus. J Comp Neurol 480:115-142. CrossRef Medline

Middleton FA, Strick PL (2000) Basal ganglia output and cognition: evidence from anatomical, behavioral, and clinical studies. Brain Cogn 42: 183-200. CrossRef Medline

Miller RLA, Bates CJ, Onos KD, Wormwood BA, Francoeur MJ, Gibson BM, Mair RG (2013) Memory coding properties of central thalamic neurons: relationship to prefrontal coding. Soc Neurosci Abstr 574.06.
Mitchell AS, Chakraborty S (2013) What does the mediodorsal thalamus do? Front Syst Neurosci 7:37. CrossRef Medline

Mitchell AS, Dalrymple-Alford JC (2005) Dissociable memory effects after medial thalamus lesions in the rat. Eur J Neurosci 22:973-985. CrossRef Medline

Mitchell AS, Gaffan D (2008) The magnocellular mediodorsal thalamus is necessary for memory acquisition, but not retrieval. J Neurosci 28:258 263. CrossRef Medline

Mitchell AS, Baxter MG, Gaffan D (2007) Dissociable performance on scene learning and strategy implementation after lesions to magnocellular mediodorsal thalamic nucleus. J Neurosci 27:11888-11895. CrossRef Medline

Mitchell AS, Browning PG, Wilson CR, Baxter MG, Gaffan D (2008) Dissociable roles for cortical and subcortical structures in memory retrieval and acquisition. J Neurosci 28:8387-8396. CrossRef Medline

Moga MM, Weis RP, Moore RY (1995) Efferent projections of the paraventricular thalamic nucleus in the rat. J Comp Neurol 359:221-238. CrossRef Medline

Morison RS, Dempsey EW (1941) A study of thalamo-cortical relations. Am J Physiol 135:281-292.

Onos KD, Wormwood BA, Miller RLA, Francoeur MJ, Herbert EF, Blake AW, Gibson BM, Mair RG (2013) Memory coding properties of prefrontal cortical neurons in the rat. Soc Neurosci Abstr 574-07.

Ostendorf F, Liebermann D, Ploner CJ (2010) Human thalamus contributes to perceptual stability across eye movements. Proc Natl Acad Sci U S A 107:1229-1234. CrossRef Medline

Ostlund SB, Balleine BW (2008) Differential involvement of the basolateral amygdala and mediodorsal thalamus in instrumental action selection. J Neurosci 28:4398-4405. CrossRef Medline

Parnaudeau S, O’Neill PK, Bolkan SS, Ward RD, Abbas AI, Roth BL, Balsam PD, Gordon JA, Kellendonk C (2013) Inhibition of mediodorsal thalamus disrupts thalamofrontal connectivity and cognition. Neuron 77 : 1151-1162. CrossRef Medline

Parnaudeau S, Taylor K, Bolkan SS, Ward RD, Balsam PD, Kellendonk C (2014) Mediodorsal thalamus hypofunction impairs flexible goaldirected behavior. Biol Psychiatry pii:S0006. CrossRef Medline

Prasad JA, Chudasama Y (2013) Viral tracing identifies parallel disynaptic pathways to the hippocampus. J Neurosci 33:8494-8503. CrossRef Medline

Rafal RD, Posner MI (1987) Deficits in human visual spatial attention following thalamic lesions. Proc Natl Acad Sci U S A 84:7349-7353. CrossRef Medline

Romanides AJ, Duffy P, Kalivas PW (1999) Glutamatergic and dopaminergic afferents to the prefrontal cortex regulate spatial working memory in rats. Neuroscience 92:97-106. CrossRef Medline

Royce GJ, Bromley S, Gracco C, Beckstead RM (1989) Thalamocortical connections of the rostral intralaminar nuclei: an autoradiographic analysis in the cat. J Comp Neurol 288:555-582. CrossRef Medline

Russchen FT, Amaral DG, Price JL (1987) The afferent input to the magnocellular division of the mediodorsal thalamic nucleus in the monkey, Macaca fascicularis. J Comp Neurol 256:175-210. CrossRef Medline

Sakai ST, Inase M, Tanji J (2002) The relationship between MI and SMA afferents and cerebellar and pallidal efferents in the macaque monkey. Somatosens Mot Res 19:139-148. CrossRef Medline

Saunders RC, Mishkin M, Aggleton JP (2005) Projections from the entorhinal cortex, perirhinal cortex, presubiculum, and parasubiculum to the medial thalamus in macaque monkeys: identifying different pathways using disconnection techniques. Exp Brain Res 167:1-16. CrossRef Medline

Schwartz ML, Dekker JJ, Goldman-Rakic PS (1991) Dual mode of corticothalamic synaptic termination in the mediodorsal nucleus of the rhesus monkey. J Comp Neurol 309:289-304. CrossRef Medline

Sherman SM (2007) The thalamus is more than just a relay. Curr Opin Neurobiol 17:417-422. CrossRef Medline

Sherman SM (2012) Thalamocortical interactions. Curr Opin Neurobiol 22:575-579. CrossRef Medline

Sherman SM, Guillery RW (1996) Functional organization of thalamocortical relays. J Neurophysiol 76:1367-1395. Medline

Sherman SM, Guillery RW (2002) The role of the thalamus in the flow of information to the cortex. Philos Trans R Soc Lond B Biol Sci 357:16951708. CrossRef Medline

Shin S, Sommer MA (2012) Division of labor in frontal eye field neurons 
during presaccadic remapping of visual receptive fields. J Neurophysiol 108:2144-2159. CrossRef Medline

Sommer MA, Wurtz RH (2002) A pathway in primate brain for internal monitoring of movements. Science 296:1480-1482. CrossRef Medline

Sommer MA, Wurtz RH (2004a) What the brain stem tells the frontal cortex. I. Oculomotor signals sent from superior colliculus to frontal eye field via mediodorsal thalamus. J Neurophysiol 91:1381-1402. CrossRef Medline

Sommer MA, Wurtz RH (2004b) What the brain stem tells the frontal cortex. II. Role of the SC-MD-FEF pathway in corollary discharge. J Neurophysiol 91:1403-1423. CrossRef Medline

Sommer MA, Wurtz RH (2006) Influence of the thalamus on spatial visual processing in frontal cortex. Nature 444:374-377. CrossRef Medline

Sommer MA, Wurtz RH (2008) Brain circuits for the internal monitoring of movements. Annu Rev Neurosci 31:317-338. CrossRef Medline

Stanton GB, Goldberg ME, Bruce CJ (1988) Frontal eye field efferents in the macaque monkey: I. Subcortical pathways and topography of striatal and thalamic terminal fields. J Comp Neurol 271:473-492. CrossRef Medline

Steriade M, Datta S, Paré D, Oakson G, Curró Dossi RC (1990) Neuronal activities in brain-stem cholinergic nuclei related to tonic activation processes in thalamocortical systems. J Neurosci 10:2541-2559. Medline

Steriade M, Jones EG, McCormick DA (1997) Thalamus. Elsevier: Amsterdam.

Stokes KA, Best PJ (1990) Response biases do not underlie the radial maze deficit in rats with mediodorsal thalamus lesions. Behav Neural Biol 53: 334-345. CrossRef Medline

Su HS, Bentivoglio M (1990) Thalamic midline cell populations projecting to the nucleus accumbens, amygdala, and hippocampus in the rat. J Comp Neurol 297:582-593. CrossRef Medline

Theyel BB, Lee CC, Sherman SM (2010) Specific and nonspecific thalamocortical connectivity in the auditory and somatosensory thalamocortical slices. Neuroreport 21:861-864. CrossRef Medline

Valenstein E, Bowers D, Verfaellie M, Heilman KM, Day A, Watson RT (1987) Retrosplenial amnesia. Brain 110:1631-1646. CrossRef Medline

Van der Werf YD, Witter MP, Groenewegen HJ (2002) The intralaminar and midline nuclei of the thalamus: anatomical and functional evidence for participation in processes of arousal and awareness. Brain Res Rev 39:107-140. CrossRef Medline
Van der Werf YD, Scheltens P, Lindeboom J, Witter MP, Uylings HB, Jolles J (2003) Deficits of memory, executive functioning and attention following infarction in the thalamus: a study of 22 cases with localised lesions. Neuropsychologia 41:1330-1344. CrossRef Medline

Vertes RP (2004) Differential projections of the infralimbic and prelimbic cortex in the rat. Synapse 51:32-58. CrossRef Medline

Vertes RP (2002) Analysis of projections from the medial prefrontal cortex to the thalamus in the rat, with emphasis on nucleus reuniens. J Comp Neurol 442:163-187. CrossRef Medline

Vertes RP, Hoover WB (2008) Projections of the paraventricular and paratenial nuclei of the dorsal midline thalamus in the rat. J Comp Neurol 508:212-237. CrossRef Medline

Vertes RP, Hoover WB, Do Valle AC, Sherman A, Rodriguez JJ (2006) Efferent projections of reuniens and rhomboid nuclei of the thalamus in the rat. J Comp Neurol 499:768-796. CrossRef Medline

Vertes RP, Hoover WB, Szigeti-Buck K, Leranth C (2007) Nucleus reuniens of the midline thalamus: link between the medial prefrontal cortex and the hippocampus. Brain Res Bull 71:601-609. CrossRef Medline

Vertes RP, Hoover WB, Rodriguez JJ (2012) Projections of the central medial nucleus of the thalamus in the rat: node in cortical, striatal and limbic forebrain circuitry. Neuroscience 219:120-136. CrossRef Medline

Viaene AN, Petrof I, Sherman SM (2011) Synaptic properties of thalamic input to layers $2 / 3$ and 4 of primary somatosensory and auditory cortices. J Neurophysiol 105:279-292. CrossRef Medline

Wouterlood FG, Saldana E, Witter MP (1990) Projection from the nucleus reuniens thalami to the hippocampal region: light and electron microscopic tracing study in the rat with the anterograde tracer Phaseolus vulgaris-leucoagglutinin. J Comp Neurol 296:179-203. CrossRef Medline

Wurtz RH, Sommer MA (2004) Identifying corollary discharges for movement in the primate brain. Prog Brain Res 144:47-60. CrossRef Medline

Wurtz RH, McAlonan K, Cavanaugh J, Berman RA (2011) Thalamic pathways for active vision. Trends Cogn Sci 15:177-184. CrossRef Medline

Xu W, Südhof TC (2013) A neural circuit for memory specificity and generalization. Science 339:1290-1295. CrossRef Medline 